\title{
The uptake of D-araboascorbic acid (D-isoascorbic acid) by guinea-pig tissues
}

\author{
By R. E. HUGHES AND R. J. HURLEY \\ University of Wales Institute of Science and Technology, Cardiff, Wales
}

(Received 23 May I968-Accepted 4 November 1968)

\begin{abstract}
I. Guinea-pigs on a low, controlled intake of ascorbic acid $(0.3 \mathrm{mg} / \mathrm{r} 00 \mathrm{~g}$ body-weight) were given daily an oral supplement of L-ascorbic acid (AA) or of D-isoascorbic acid (isoAA) (both $1.5 \mathrm{mg} / \mathrm{roo} \mathrm{g}$ body-weight). The AA was deposited in the tissues, the isoAA was not.

2. Intramuscularly administered isoAA was deposited in the tissues but not to the same extent as equivalent amounts of intramuscularly administered AA.

3. Paper chromatography confirmed that intramuscularly administered isoAA was deposited in the tissues as isoAA, i.e. there was no conversion into $\mathrm{AA}$.

4. It is concluded that in guinea-pigs $(a) \mathrm{AA}$ is absorbed from the gastro-intestinal tract much more readily than isoAA and $(b) \mathrm{AA}$ is either more readily abstracted from the blood or is more readily retained by the tissues or both, than is isoAA.
\end{abstract}

Until the biochemical systems in which vitamin $\mathrm{C}$ is involved have been fully characterized and reconstructed in vitro no definite statement can be made regarding the biochemical specificity of the ascorbic acids. Statements to the effect that L-ascorbic acid (L-xyloascorbic acid) (AA) has considerably greater activity than certain structurally related compounds have almost invariably been based on the results of dietary experiments and are frequently at variance with our knowledge of the behaviour of these compounds in biochemical systems. Thus D-araboascorbic acid (D-isoascorbic acid) (isoAA) is reported to have only one-twentieth of the vitamin activity of L-xyloascorbic acid, the naturally occurring isomer. This is in marked contrast to the known ability of iso $A A$ and dehydroiso $A A$ to replace $A A$ and dehydroAA respectively in biochemical systems such as those involving ascorbic acid oxidase and glutathione: dehydroascorbate oxidoreductase (Dodds, I948; Hughes, 1964; Grimble \& Hughes, I967).

Obviously 'vitamin activity' as measured by feeding experiments is an unreliable guide to the true biochemical specificity operating at the cellular level. A substance could well be judged 'inactive' on the basis of feeding trials simply because it does not reach the sites of active metabolism in sufficient quantities. Feeding experiments alone do not take into account physiological factors such as barriers to absorption, membrane selectivity and low or defective tissue retention.

Recent work has underlined this point. Hughes \& Maton (1968), using the isolated erythrocyte to provide a model physiological membrane system, confirmed the finding of previous workers (e.g. Raiha, 1958) that vitamin C crosses biological membranes in the oxidized form, i.e. as dehydro-ascorbic acid. They further showed that there was virtually no uptake of dehydroisoAA (dehydro-D-araboascorbic acid) under conditions that permitted a rapid uptake of dehydroAA (dehydro-L-xyloascorbic acid). It is therefore conceivable that the apparent specificity of AA as an antiscorbutic 
agent is not so much a specificity in biochemical terms as a reflection of a selectivity imposed by certain natural membranes.

The experiments reported in this paper were designed to compare the uptake by guinea-pig tissues of similar doses of AA and isoAA.

\section{EXPERIMENTAL}

\section{Animals and diet}

Male albino guinea-pigs of initial body-weight $c .300 \mathrm{~g}$ were used. The diet had the following composition (g): ground oats 37 , wheat bran 35 , dried skim milk ( $\mathrm{I} \%$ fat) Io, dried full cream milk ( $26.5 \%$ fat) Io, dried yeast 6.5 , salt mixture $\mathrm{I} \cdot 0$, and magnesium oxide 0.5 . The dried milks were from Unigate (Milk Products) Ltd, the dried yeast from Distillers Co. (Yeast) Ltd, and the salt mixture from Glaxo Research Ltd. Before incorporation into the diet the milk powders were heated for $24 \mathrm{~h}$ at $110^{\circ}$ to destroy any residual vitamin C. Each animal was given a weekly supplement of $0.5 \mathrm{ml}$ of $5 \%$ menaphthone in arachis oil, $0.05 \mathrm{ml}$ of cod-liver oil and $10 \mathrm{~g}$ of hay. When supplemented with L-ascorbic acid, the diet supported normal growth of guinea-pigs. Without the ascorbic acid the guinea-pigs developed scurvy.

The guinea-pigs were housed in individual galvanized zinc cages, with removable $\frac{7}{16}$ in. mesh bottoms. Pair-feeding was not practised, as previous work had indicated that moderate changes in the vitamin $\mathrm{C}$ intake had no appreciable effect on food intake (Evans \& Hughes, 1963). The animals were weighed daily.

\section{Ascorbic acids}

L-ascorbic acid was obtained from British Drug Houses Ltd and isoascorbic acid from Koch-Light Ltd. Solutions containing the calculated amounts were prepared in glass-distilled water immediately before use, and given, intramuscularly by injection into the hind leg or orally, on a body-weight basis. The concentration of the solutions was adjusted so that $O \cdot \mathrm{I} \mathrm{ml}$ was administered per $100 \mathrm{~g}$.

$\mathrm{AA}$ and isoAA levels in the tissues were determined photometrically by measuring the degree of reduction of a standard acidic solution of the redox dye, phenol-indo-2: 6dichlorophenol (Bessey, 1938; Hughes, 1956). Preliminary experiments confirmed that equal weights of the two acids reduced the dye to the same extent. In experiments involving the simultaneous administration of both isomers, the 'total ascorbic acid' in the tissues (Tables I and 2) is therefore the sum of the isoAA and the AA.

\section{Paper chromatography}

Paper chromatography was used to establish that the isomer administered was the one actually deposited in the tissues.

The animals were killed by beheading. Their adrenal glands were quickly dissected out and ground with a little sand and $\mathrm{r} \mathrm{ml}$ of a solution containing $0.67 \%$ metaphosphoric acid and $0.33 \%$ diamino-ethanetetra-acetic acid, sodium salt (EDTA). The extract was centrifuged and $0.005^{-0.010} \mathrm{ml}$ of the supernatant fraction was applied to the chromatography paper; $0.0 \mathrm{I} \mathrm{ml}$ of solutions of $\mathrm{AA}$ and of isoAA 
(both containing $10 \mathrm{mg}$ in $100 \mathrm{ml}$ of the metaphosphoric acid-EDTA solution) were applied to each paper as standards. The papers were equilibrated in the chromatography tank for $45 \mathrm{~min}$, and the isomers were separated by descending chromatography using acetonitrile:acetone:water:glacial acetic acid $(80: 5: 15: 1 \cdot 2)$ as the solvent mixture (Kadin \& Osadca, 1959). The preliminary impregnation of the paper with $2 \%$ metaphosphoric acid as suggested by Kadin \& Osadca (1959) was omitted, since clearer separations were obtained with the untreated paper.

\section{Plan of experiments}

Three experiments were done.

Expt I. Expt I was designed to compare the tissue levels resulting from oral dosing with the same amounts of AA and isoAA. Three groups of eight animals were used. All three groups received a daily supplement of $0.3 \mathrm{mg} \mathrm{AA} / \mathrm{roo} g$ to satisfy normal growth requirements. Group $\mathrm{A}$ received no additional supplement. Group $\mathrm{C}$ received a further $1.5 \mathrm{mg} \mathrm{AA} / 100 \mathrm{~g}$ and group $\mathrm{B} \mathrm{I}_{5} \mathrm{mg}$ isoAA/100 g. The experiment continued for $4 \circ$ days. The guinea-pigs were killed and total ascorbic acid in the spleen and adrenal glands was determined.

Expt 2. Expt 2 was designed to extend the findings of Expt $\mathrm{x}$. Three groups of six animals were used. The dosage levels and distributions between the groups were as in Expt I but the supplements were given intramuscularly instead of orally. The experiment continued for 3 weeks. Continuation beyond this period was impracticable because of the effect of the repeated injections on the hind-leg muscles.

Expt. 3. Expt 3 was done to establish whether the isomer deposited in the tissues was the one administered, i.e. that there was no conversion of isoAA into AA, as could conceivably occur were an appropriate isomerase present. Four guinea-pigs were used. They were depleted of ascorbic acid by being given the unsupplemented scorbutogenic diet for Io days. Two were injected intramuscularly with $\mathrm{AA}(3 \mathrm{mg} / \mathrm{I} 00 \mathrm{~g}$ body-weight) and two with isoAA ( $3 \mathrm{mg} / \mathrm{roog}$ body-weight) daily for a period of 4 days. At the end of this period paper chromatography was used to identify the isomer deposited in the adrenals of each animal. At the same time, the concentration of the injected acid in the spleen was determined by the photometric method (see p. 212).

\section{RESULTS}

The results are summarized in Tables $I$ and 2. In the guinea-pigs dosed orally (Expt I) the group A animals $(0.3 \mathrm{mg} / \mathrm{roo} \mathrm{g}$ body-weight) had adrenal and spleen concentrations of 27.0 and $10.2 \mathrm{mg} \mathrm{AA} / 100 \mathrm{~g}$ respectively. The oral intake of an additional $\mathrm{I} \cdot 5 \mathrm{mg} \mathrm{AA} / \mathrm{roO} \mathrm{g}$ (group C) raised these values to 64.3 and $\mathrm{I} \cdot 6$ respectively, but the administration of a similar amount of isoAA (group B) produced no such increase. This suggests that isoAA, unlike AA, is not deposited in the tissues when given orally at a level of $\mathrm{I} \cdot 5 \mathrm{mg} / \mathrm{ro0} \mathrm{g}$.

The results of Expt 2 (intramuscular injection) indicate the extent to which this difference is attributable to defective gastro-intestinal absorption of isoAA. The total ascorbic acid in the adrenals of the 'isoAA' group was increased from $2 \mathrm{I}^{\cdot} 5$ to $52^{\circ} 5$ $\mathrm{mg} / \mathrm{roog}$ and in the spleen from 6.99 to $\mathrm{I}$ I.22. However, the tissue levels still fell short 
of those obtained by injecting a corresponding amount of AA (94.0 and $31.8 \mathrm{mg} / \mathrm{ro0} \mathrm{g}$ tissue for adrenals and spleen respectively). In Expt I there was no significant difference between the total ascorbic acid levels in the tissues of groups A and B; in Expt 2 the difference was highly significant $(P<0.01)$.

The results of Expt 3 indicated that the isomer deposited in the adrenal glands was the one administered.

In the two guinea-pigs injected with isoAA the $R_{F}$ values of the isomer deposited in the adrenal glands were 0.39 and 0.40 ; in the guinea-pigs injected with AA the $R_{F}$ values were 0.36 and 0.35 . The $R_{F}$ values for AA and isoAA standards were 0.35 and 0.40 respectively.

The levels of isoAA deposited in the spleens were 8.23 and $18.01 \mathrm{mg} / \mathrm{roo} \mathrm{g}$. The corresponding values for the guinea-pigs injected with AA were 28.50 and 33.40 $\mathrm{mg} / \mathrm{I} 00 \mathrm{~g}$ respectively. These results are in agreement with the results obtained in Expt 2, the isoAA concentration being about half that resulting from a corresponding injection of AA.

Table I. Expt I : Effect of dosing orally with ascorbic acid $(A A)$ and isoascorbic acid (iso $A A$ ) on the tissue concentrations of 'total ascorbic acid' in guinea-pig spleen and adrenals. Results are given as mean values with standard errors

\begin{tabular}{|c|c|c|c|c|c|c|c|c|c|}
\hline & $\begin{array}{r}\mathrm{D} \\
\text { supple } \\
\text { (mg }\end{array}$ & ent & & & & Adr & & & \\
\hline roup & body & isoAA & $\begin{array}{c}\text { Initial } \\
\text { body-wt } \\
(\mathrm{g})\end{array}$ & $\begin{array}{l}\text { Final } \\
\text { body-wt } \\
\text { (g) }\end{array}$ & $\begin{array}{l}\text { Weight } \\
\text { (mg) }\end{array}$ & $\begin{array}{c}\text { Wt as } \\
\% \text { of } \\
\text { body-wt* }\end{array}$ & $\begin{array}{l}\text { Total } \\
\text { ascorbic acid } \\
(\mathrm{mg} / \mathrm{l} 00 \mathrm{~g})^{*}\end{array}$ & $\begin{array}{l}\text { Weight } \\
\text { (mg) }\end{array}$ & $\begin{array}{c}\text { Total } \\
\text { ascorbic acid } \\
(\mathrm{mg} / \mathrm{l} 00 \mathrm{~g})^{*}\end{array}$ \\
\hline & 0.3 & $\mathbf{o}$ & $3 x \pm$ & $412 \pm 1$ & 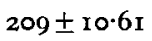 & $49 \pm$ & & 468 & \\
\hline & 0.3 & $1 \cdot 5$ & & $410 \pm 19 \cdot 45$ & & $0.052 \pm 0.0035$ & & & \\
\hline$C(6)$ & $1 \cdot 8$ & 0 & $308 \pm 7 \cdot 50$ & $452 \pm 12 \cdot 25$ & $167 \pm 5 \cdot 31$ & $0.037 \pm 0.0004$ & $64 \cdot 3 \pm 3 \cdot 18$ & $499 \pm 14 \cdot 29$ & $19.6 \pm I \cdot 10$ \\
\hline
\end{tabular}

The number of animals present in each group at the end of the experiment is given in parentheses.

* Difference between means of groups A and C significant at $0.1 \%$ level.

Table 2. Expt 2: Effect of intramuscular injection of ascorbic acid $(A A)$ and isoascorbic acid (iso $A A$ ) on the tissue concentrations of 'total ascorbic acid' in guinea-pig spleen and adrenals. Results are given as mean values with standard errors

\begin{tabular}{|c|c|c|c|c|c|c|c|c|}
\hline \multirow[b]{2}{*}{ Group } & \multirow{2}{*}{\multicolumn{2}{|c|}{$\begin{array}{l}\text { Supplement } \\
\text { (mg/roo g } \\
\text { body-wt) }\end{array}$}} & \multirow[b]{2}{*}{$\begin{array}{l}\text { Initial } \\
\text { body-wt } \\
\text { (g) }\end{array}$} & \multirow[b]{2}{*}{$\begin{array}{l}\text { Final } \\
\text { body-wt } \\
(\mathrm{g})\end{array}$} & \multicolumn{2}{|c|}{ Adrenals } & \multicolumn{2}{|c|}{ Spleen } \\
\hline & & & & & $\begin{array}{l}\text { Weight } \\
\text { (mg) }\end{array}$ & $\begin{array}{c}\text { Total } \\
\text { ascorbic acid } \\
(\mathrm{mg} / 100 \mathrm{~g})^{*}+\dagger\end{array}$ & $\begin{array}{l}\text { Weight } \\
\text { (mg) }\end{array}$ & $\begin{array}{c}\text { Total } \\
\text { ascorbic acid } \\
(\mathrm{mg} / \mathrm{I} 00 \mathrm{~g})^{* * \dagger}\end{array}$ \\
\hline$A(5)$ & 0.3 & 0 & $280 \pm 7 \cdot 16$ & $334 \pm 18 \cdot 34$ & $128 \pm 6-7$ & $2 I \cdot 5 \pm I \cdot 48$ & S & 6.99 \\
\hline $\begin{array}{l}B(4) \\
C(5)\end{array}$ & $\begin{array}{l}0.3 \\
I \cdot 8\end{array}$ & $\begin{array}{l}\mathbf{I} \cdot 5 \\
0\end{array}$ & $\begin{array}{l}272 \pm 9.5 \\
276 \pm 8.05\end{array}$ & $\begin{array}{l}310 \pm 14.5 \\
320 \pm 11 \cdot 63\end{array}$ & $\begin{array}{l}136 \pm 9 \cdot 5 \\
146 \pm 8 \cdot 05\end{array}$ & $\begin{array}{l}52 \cdot 5 \pm 5 \cdot 6 \\
94 \cdot 0 \pm 8 \cdot 7^{2}\end{array}$ & $\begin{array}{l}45^{8} \pm 56 \\
381 \pm 13.42\end{array}$ & $\begin{array}{l}\text { II.2 } 20 \cdot 78 \\
31 \cdot 8 \pm x \cdot 32\end{array}$ \\
\hline
\end{tabular}

The number of animals present in each group at the end of the experiment is given in parentheses.

* Difference between means of groups A and B significant at $0.1 \%$ level.

** Difference between means of groups A and B significant at $5 \%$ level.

$\uparrow$ Difference between means of groups $\mathrm{B}$ and $\mathrm{C}$ significant at $0.1 \%$ level.

$+\dagger$ Difference between means of groups B and $\mathbf{C}$ significant at $5 \%$ level. 


\section{DISCUSSION}

The main finding to emerge from this work is that isoAA administered orally to guinea-pigs at an intake level of $1.5 \mathrm{mg} / 100 \mathrm{~g}$ body-weight is not deposited in the body tissues. This is in striking contrast with the behaviour of an equivalent daily dose of AA administered orally. Parenteral administration of isoAA, on the other hand, increased the level of total ascorbic acid in the adrenal glands by $144 \%$ and the level in the spleen by $6 \mathrm{r} \%$. This suggests that the gastro-intestinal membrane(s) is not equally permeable to both isomers. This difference in permeability is probably at least in part responsible for the different tissue levels resulting from dosing orally with the two isomers.

A similar situation exists with the uptake of the oxidized forms of the two isomers by the isolated mammalian erythrocyte, and there is evidence that AA is absorbed from the gastro-intestinal tract of the guinea-pig, at least in part, in the oxidized form (Hughes \& Lewis, 1965; Hughes \& Maton, 1968).

The chromatographic demonstration that injected isoAA is deposited as such in the tissues indicates that there is no conversion of isoAA into AA, such as could presumably occur were the appropriate isomerase present. Also, it makes less likely the possibility that metabolic responses elicited by isoAA administration are vicarious ones resulting from a protective effect on the residual stores of $\mathrm{AA}$ in the tissues.

It may be noted that the levels of tissue AA in group A ( $0.3 \mathrm{mg} / \mathrm{roog}$ body-weight) were higher in Expt I (oral administration) than in Expt 2 (intramuscular injection), whereas in group $\mathrm{C}(\mathrm{I} .8 \mathrm{mg} / \mathrm{roog}$ body-weight) the opposite was so. At first sight these results would appear to be mutually contradictory. Two considerations should, however, be borne in mind: $(a)$ oral dosing is probably more effective at low dietary intakes of AA than at high ones (Penney \& Zilva, I946), and (b) the continued injection of the guinea-pigs in Expt 2 probably produced stress effects. Stress in guinea-pigs lowers the level of vitamin $C$ in the adrenals (Chatterjee, 1967) and this would presumably be more apparent at low levels of vitamin $\mathrm{C}$ than at high levels. Furthermore, recent work has indicated that the amount of administered AA deposited in the tissues is related to a number of factors such as sex, age and rate of growth (R. E. Hughes and P. R. Jones, unpublished observations). In Expt 2 the growth rate was less than in Expt I, probably because of the stressing effect of the injections, and this in turn would influence the tissue deposition of the vitamin C. Such differences in the basal values for different experiments do not, however, invalidate a comparison of the levels obtained in the different groups within a single experiment.

The finding that parenteral administration of isoAA did not raise the tissue levels to those obtained with AA administered parenterally means that a factor (or factors) other than a difference in gastro-intestinal absorption is involved. Thus one can visualize a second type of 'barrier system' similar to that occurring at the absorption level but interfering with the passage of the isoAA from the blood to the 'retention areas' of the tissues. Different rates of elimination by the kidneys could also be of significance. Also of relevance is the possibility of a difference in the mechanisms of retention. Fiddick \& Heath (1967) have recently shown that, in the rat adrenal, up to 
$40 \%$ of the ascorbic acid is present in a 'bound form' in association with a larger molecule. Preliminary investigations indicate that in the case of the guinea-pig adrenal gland the percentage of 'bound AA' is not large (R. E. Hughes and R. J. Hurley, unpublished observations). Nevertheless, any such binding will presumably imply a specificity on the part of the 'binding' molecule; and this could be reflected as different degrees of retention of isomeric forms of ascorbic acid. Experiments in progress have been designed to cast further light on the 'binding' of ascorbic acid isomers by tissues. In the adrenal gland, where ascorbic acid appears to have certain 'extra-antiscorbutic' involvements, any such binding between AA and a larger molecule could be of considerable metabolic significance.

During the course of this work, Fabianek \& Herp (1967) reported that large doses of isoAA (Io $\mathrm{mg} /$ day and over) could prevent the appearance of scorbutic symptoms in guinea-pigs, without producing the growth rate obtainable with much lower intakes of AA. A daily intake of $0.5 \mathrm{mg} / \mathrm{I00} \mathrm{g}$ body-weight per day failed to support growth. This latter finding is in agreement with our results. At a daily intake level of $I^{\cdot} 5 \mathrm{mg}$ isoAA/100 $\mathrm{g}$ body-weight we found no tissue deposition of isoAA; nor was the adrenal hypertrophy which is characteristic of low vitamin $\mathrm{C}$ intakes prevented (Table 2). With the larger doses used by Fabianek \& Herp (I967) presumably sufficient amounts of the isomer were absorbed to support growth.

This work was made possible by a Medical Research Council Grant.

\section{REFERENCES}

Bessey, O. A. (1938). 7. biol. Chem. 126, 771.

Chatterjee, G. C. (1967). In The Vitamins, and ed. Vol. I, p. 407. [W. H. Sebrell Jr and R. S. Harris, editors.] London and New York: Academic Press Inc.

Dodds, M. L. (1948). Archs Biochem. 18, 5 x.

Evans, J. R. \& Hughes, R. E. (1963). Br. F. Nutr. 17, 25 I.

Fabianek, J. \& Herp, A. (1967). Proc. Soc. exp. Biol. Med. 125, 462.

Fiddick, R. \& Heath, H. (1967). Biochim. biophys. Acta 136, 206.

Grimble, R. F. \& Hughes, R. E. (1967). Experientia 23, 362.

Hughes, R. E. (I956). Biochem. F. 64, 203.

Hughes, R. E. (I964). Nature, Lond. 203 , ro68.

Hughes, R. E. \& Lewis, S. C. (1965). Proc. Nutr. Soc. 24, xxxiv.

Hughes, R. E. \& Maton, S. C. (1968). Br. F. Haemat. 14, 247.

Kadin, H. \& Osadca, M. (r959). F. agric. Chem. Soc. Fapan 7, 358.

Penney, J. R. \& Zilva, S. S. (1946). Biochem. F. 40, 695.

Raiha, N. (1958). Acta physiol. Scand. 45, Suppl. I 55, p. 24. 